let under our kitchen window, a Clay-colored, a Harris', and two Tree Sparrows were daily visitors. What a wonderful chance to observe birds at close range!

A mild spell in the latiter part of Ootober sent about 300 ducks through here on October 24. Also, on October 24, I saw a Greater Yellowlegis. On
October 21, there was an exhausted Common Snipe wandering among the cattle in our barnyard. How these birds survived the blizzards is a deep mystery to me. Many, of course, did not survive, and it would have been impossible to estimate the number of birds killed by the blizzard in the Oak Lake marshes alone.

\title{
Saskatchewan Birds in August, 1959
}

\section{As Noted by J. Murray Speirs and Doris H. Speirs, Pickering, Ont.}

August 19 was a cool, overcast day with frequen't thundershowers and a chill wind from the northeast. In the morning we drove east along Manitoba's Highway 19 for nine miles to the spot where we had seen a pair of Northern Three-toed Woodpeckers the night before, where Olive-sided Flycatchers called and a Lincoln's Sparrow sang. In the morning drizzle we did not venture from the car: a big bull moose stared at us from the shadows under the evergreens and a group of Boreal Chickadees uttered their nasal version of che Black-capped Chickadee's call. We left our boreal friends and drove south through Brandon, then west through Virden, reaching the Saskatchewan border at 5.20 p.m. We had hoped to spend the night at Moose Mountain but were advised against trying the road down in the pouring rain. There was a brief flash of sun just before sunset and a Clay-colored Sparrow sang as we turned in at Moosomin.

Next morning, August 20, we drove in to Regina, passing a flock of about 80 Black-billed Magpies between Whitewood and Grenfell and stopping to admire a beautiful pair of Krider's Red-tailed Hawks between Indian Head and Regina. One had a white head and tail and big white wing patches; the other was similar but with a tinge of red on the terminal third of its tail. The call was not so guttural as that of our eastern red-tails. We had our first view of the beautiful new museum in Regina and had lunch with our friends Robert Nero and the Hamerstroms (also arrived early for the A.O.U., from Wisconsin). We decided to head for the Cypress Hills and turned in early again on another stormy night ait Moose Jaw.

Aug. 21 was a seraphic day and we set forth from Moose Jaw in high anticipation. Before we reached Mortlach we stopped to admire a lovely patch of roadside sage, fresh washed by several days of rain, when out burst a flock of six Sharp-tailed Grouse, our first on this western trip. We had hardly started up when a family of Gray Partridge was spotted on the far side of the rcad. Near the salty Lake Chaplin we saw our first Willet for Saskatchewan and 35 Avocets (as Dr. Nero had predicted). The highlight of the morning was Reed Lake. It was full of ducks of at least nine species including a Gadwall with four young. Its shores were lined with Franklin's and Ring-billed Gulls with a good sprinkling of shorebirds including 2 Wilscn's Phalaropes. We stopped to investigate a road kill and found that it was a Short-eared Owl. Another road kill proved to be a porcupine: what do porcupines live on out in the open prairies far from any trees? We arrived at Cypress Hills in mid-afternoon, only to find the available accommodation solidly booked. As it was early we decided to look around, having left our name in case a vacancy should turn up. Black-capped Chickadees were omnipresent as were the rather pale Oregon Juncos and Audubon's Warblers. Red Crossbills flew over, calling "yip, yip" from time to time. In late afternoon a cabin became available and we moved in, lit a fire and opened windows as the cabin appeared to have a striped tenant below the floor. This joint tenancy became more and more dif- 
ficult as time progressed and we were relieved when another cabin became available and we were able to move there before nightfall.

As we walked around the little lake in the evening we found a Solitary Sandpiper patrolling its shore, and the singing of a Ruby-crowned Kinglet and the flight song of MacGillivray's Warbler added to the beauty of the place. We did not see the kinglet that evening, but the next day we saw at least four, including an adult feeding young. My recollection is that there may have been more than four but the birds were very high up in the tall evergreens. The begging calls of the young were unfamiliar to me and the birds were too high to identify properly that day, but on the morning of August 24 I was able to get a satisfactory view of two of the birds and they were definitely Ruby-crowned, not Golden-crowned Kinglets. We did not find any Golden-crowned Kinglets in the park during our visit.

We explored the park all the next day, finding four more Sharp-tailed Grouse and hearing a Lincoln's Sparrow singing near headquarters. The Lincoln's Sparrow was singing from the scrub willows that occupy the "lake bed" and since this is the species we are writing up for Bent we spent some time observing at this spot. On the morning of August 24 before we left the park an adult was seen feeding a young bird there.

The highlight of the 23rd was a visit to Cypress Lake where we saw some 200 Eared Grebes including one very conspicuous albino. There were 10 kinds of ducks including about 80 Ruddy Ducks. A single Avocet accompanied many other shorebirds of nine species on the shores. Out with the ducks a Wilson's Phalarope and 57 Northern Phalaropes rode the waves. Over the lake were five Forster's Terns and 25 Black Terns. On the way from the park we saw a Say's Phoebe, two Loggerhead Shrikes and photographed a Swainson's Hawk just as it took off from a roadside pole. Back at the park we were glad to see an Orange-crowned Warbler and five more Red Crossbills.

On the morning of the 24th we saw a Pine Siskin and two Purple Finches and a great movement of Robins before leaving to return to Regina. At Crane Lake we estimated
6000 Franklin's Gulls. Our only Prairie Falcon of the trip was seen near this spot too.

Between Swift Current and Herbert we stopped to see what we could find in a roadside shelter belt. A possible Lark Sparrow had dashed in. Quite a strong northwest wind was blowing. On the lee side we found about a dozen Eastern Kingbirds and two Western Kingibirds (our first of the trip). Another smaller Flycatcher (probably a Least), a Yellow Warbler and 5 Clay-colored Sparrows (but, alas, no Lark Sparrow). Reed Lake was again full of waterfowl including an estimated 700 Canvasbacks but only one Redhead that we could find. We made a detour up to Riverhurst from Uren seeing many Mallards, Pintails and Blue-winged Teal in little potholes en route. The Western Meadowlarks and Brewer's Blackbirds were of interest to eastern eyes. From August 25 to 29 we attended the sessions of the A.O.U. at Regina.

The highlights of the early morning field trip just south of Regina on August 26 were, of course, the Burrowing Owls and the roadside pond with Dowitchers and Marbled Godwits. We were also glad to see the Chestnut-collared Longspur and Richardson's Ground Squirrel. Margaret Belcher tcok a party of us to look for Baird's Sparrows on the afternoon of August 27. We found no Baird's but did see two Western King:birds, two Black-billed Magpies, several Loggerhead Shrikes and a lovely Red Fox. A Western Meadowlark uttered a dry rattle, very like a longspur's call, a new note to me. That evening I followed the local Robins to their roost site just south of Parliament Buildings where I found about 200 with as many Crows and about 100 Common Grackles in lively conversation before retiring for the night. On August 28, we visited Rock Wrens at their own private castle ( 3 slabs of concrete) by Wascana Lake and went searching for Baird's Sparrows again with Roger Tory Peterson, Dr. A. E. Allin and George W. North, again with no success.

The "official" field trip on the 29th was the big event of our stay in Saskatchewan, with its White Pelicans, Western Grebes, thousands of Sandhill Cranes, Sprague's Pipit 
(countesy of Roger Tory Peiterson), and Chestnut-collared Longsipurs. On the f.nal field trip, to the Qu'Appelle Valley with Dr. Stuart Housiton on August 30, we saw more species than we did on the big field trip the previous day with such species as Catbird, Veery, Red-eyed Vireo and American Redstart as. well as more western birds, like Western Grebes, White Pelicans and Harlan's Hawk. We spent the night of the 30 th at Moose Mountain having missed out on this visit when we first arrived in Saskatchewan. Here we saw a Common Loon, five Bonaparte Gulls, a Yellow-bellied Sapsucker, a Leasit Flycatcher and two Myrtle Warblers, as well as another Pine Siskin. On August 31 we started home for Ontario, going south from Moose Mountain to Carlyle, then east to Souris, Manitoba. We saw a Pied-billed Grebe before we reached Carlyle, a very productive shorebird puddle near Wauchope, with two Baird's Sandpipers and three Stilt Sandpipers with many Pectorals, Leasts and Semi-palmateds. We had hoped to see Mountain Bluebirds in Saskatchewan but missed them until just over the border en route to Souris, when we had a fine view of two by the roadside.

Our previous visit to Saskatchewan was from July 13 to 16,1953 . A summary of our observations during that visit. was published in the Blue Jay (XI: 25, Oct.-Dec., 1953). For comparison a summary of this year's observations may be of interest.

SPECIES LIST: Common Loon (3); Eared Grebe (202); Western Grebe (25); Piedbilled Grebe (6); White Pelican (30); Double-crested Cormorant (4); Great Blue Heron (7); American Bittern (1); Mute Swan (15); Whistling Swan (4); Canada Goose (34); Mallard (1417); Gadwall (39); Pintail (83); Green-winged Teal (40); Blue-winged Teal (746); American Widgeon (140); Shoveler (488); Redhead (22); Ring-necked Duck (3); Canvasback (832); Lesser Scaup (10); Common Goldeneye (5); Ruddy Duck (81); Hooded Merganser (5); Sharp-shinned Hawk (possibly Cooper's-poor view) (1); Redtailed Hawk (20); Harlan's Hawk (2); Swainson's Hawk (34); Marsh Hawk (58); Prairie Falcon (1); Sparrow Hawk (16); Sharp-tailed Grouse (17); Gray Partridge (10); Sandhill Crane (4000); Soral (1); American Cook (337); Semi-palmated Plover (2); Killdeer (43); Black-bellied Plover (3); Upland Plover (1); Spotted Sandpiper (5); Solitary Sandpiper (5); Willet (6); Greater Yellowlegs ( 31 ); Lesser Yellowlegs (60); Pectoral Sandpiper (106); Baird's Sandpiper (32); Least Sandpiper (60); Long-billed Dowitcher (612); Stilt Sandpiper
(3); Semipalmated Sandpiper (158); Marbled Godwit (13); Sanderling (60); American Avocet (38); Wilson's Phalarope (27); Northern Phalarope (57); Herring Gull (31); Ring-billed Gull (823); Franklin's Gull (9221); Bonaparte's Gull (8); Forster's Tern (5); Common Tern (19); Black Tern (44); Mourning Dove (90); Burrowing Owl (11); Short-eared Owl ( 1 dead); Common Nighthawk (20); Ruby-throated Hummingbird (2);

Belted Kingfisher (11); Yellow-shafted Flicker (10); Yellow-bellied Sapsucker (1); Hairy Woodpecker (3); Downy Wood pecker (4); Eastern Kingbird (199); Western Kingbird (6); Say's Phoebe (2); Least Flycatcher (7); Western Wood Pewee (1); Horned Lark (23); Tree Swallow (3); Bank Swallow (127); Rough-winged Swallow (1, good view with telescope); Barn Swallow (426); Cliff Swallow (7); Purple Martin (24); Blackbilled Magpie (118); Common Crow (4329); Black-capped Chickadee (42); Red-breasted Nuthatch (12); House Wren (19); Rock Wren (3); Catbird (3); Robin (291); Veery (1); Ruby-crowned Kinglet (10); Sprague's Pipit (1); Cedar Waxwing (21); Loggerhead Shrike (18); Starling (174); Red-eyed Vireo (3); Black-and-White Warbler (1); Tennessee Warbler (1); Orange-crowned Warbler (5); Nashville Warbler (1); Yellow Warbler (19); Myrtle Warbler (3); Audubon's Warbler (36); Northern Waterthrush (3); MacGillivray's Warbler (3); Yellowthroat (17); Wilson's Warbler (1); American Redstart (4); House Sparrow (660); Bobolink (1); Western Meadowlark (106); Yellow-headed Blackbird (78); Redwinged Blackbird (590); Brewer's Blackbird (430); Common Grackle (191); Brown-headed Cowbird (8); Rose-breasted Crosbeak (possibly Black-headed; just heard) (1): Purple Finch (3); Pine Siskin (5); American Goldfinch (44); Red Crossbill (15); Lark Bunting (2); Savannah Sparrow (46); Vesper Sparrow (20); Lark (?) Sparrow-poor view (1); Oregon Junco (149); Chipping Sparrow (44); Clay-colored Sparrow (33); Lincoln's Sparrow (3); Song Sparrow (7); Chestnut-collared Longspur (12).

From July 13-16, 1953, we saw 86 species in Saskatchewan, 12 of which were not seen during our 1959 visit in August: Red-necked Grebe, Horned Grebe, Ring-necked Pheasant, Common Snipe, Eastern Phoebe, Longbilled Marsh Wren, Brown Thrasher, Mountain Bluebird, Warbling Vireo, Baltimore Oriole, Baird's Sparrow and Le Conte's Sparrow. In 1959 we saw 136 species during our stay in Saskatchewan of which 62 were not seen during our 1953 visit; 74 species are common to the two lists. Far more individual birds were seen during our 1959 trip than in 19:53: the totals for three species in 1959-(Franklin's Gull, Common Crow and Sandhill Crane)-far exceeded the grand total of 2708 for all species in 1953. 